\title{
THE RELATIONSHIP BETWEEN SELECTED FINANCIAL INDICATORS AND LIQUIDITY OF COMPANIES IN SELECTED SECTOR IN THE CZECH REPUBLIC
}

\author{
[Vztah mezi vybranými finančními ukazateli a likviditou podniků ve vybraných \\ odvětvích v České republice]
}

\author{
Markéta Šeligová ${ }^{1}$ \\ ${ }^{1}$ Slezská univerzita, Obchodně podnikatelská fakulta, Univerzitní nám. 1934/3,733 40 Karviná \\ Email:seligova@email.cz
}

\begin{abstract}
The aim of this paper is to determine the impact of the selected financial indicators on liquidity of companies in selected sectors in the Czech Republic from 2000 to 2015. With the purpose to fulfill the aim, we examine existence and character of relationship between selected financial indicators (debt equity ratio, return on equity, share of fixed assets to total assets, share of earnings before interest and taxes to total assets) and liquidity of the companies in sectors such as mining and quarrying, manufacturing, construction, service sector and energy sector. The existence of relationship between financial indicators and liquidity of companies is tested by correlation analysis and regression analysis. The results show that there is the negative impact of share of fixed assets to total assets on liquidity of companies in service sector in the Czech Republic. The results also confirm a positive influence of return on equity on liquidity of companies and negative influence of debt equity ratio on liquidity of companies in energy sector in the Czech Republic.
\end{abstract}

Keywords: correlation, debt equity ratio, fixed assets, leverage ratio, liquidity, regression analysis, return on equity.

JEL classification: G32

Doručeno redakci: 9.2.2017; Recenzováno: 11.2.2017; 1.4.2017; Schváleno k publikování: 31.5.2017

\section{Úvod}

Myers (2001) se domníval, že agenturní účinky různých druhů mohou vytvářet významné důvody pro držbu likvidních aktiv s dalšími důsledky různých modelů řízení likvidity $\mathrm{v}$ závislosti na kapitálovou strukturu či jiné firemní vlastnosti či charakteristiky. Domníval se, že držba likvidních aktiv bude důležitá pro firmy, jež čelí růstovým př́ležitostem, a jejichž očekávaný výnos kolísá $\mathrm{v}$ průběhu času. Vzhledem $\mathrm{k}$ tomu, že se rozhodnutí týkající se likvidity pojí s dluhovou strukturou firem, každá z nich potřebuje sledovat své likvidní vztahy v návaznosti na dluhová rozhodnutí. Likvidita je klíčovým finančním ukazatelem, jež měří, zda je firma schopna plnit své dluhové závazky na základě krátkodobé, dlouhodobé a celkové míry zadlužení, aniž by došlo k nežádoucím ztrátám.

Stulz (1990) tvrdí, že firmy s vysokým pákovým efekt, a které již ztrácejí finanční flexibilitu, mohou mít potíže při hledání nových finančních zdrojů pro financování svých projektů. Nicméně, určitá úroveň dluhu či zadlužení nemusí značně znamenat negativní jev společnosti. Pokud je dluh pravidelně monitorován, objem zadlužení je pod kontrolou a vypůjčené prostředky jsou použity vhodně, pak pákový efekt může vést ke zvýšení návratnosti investic. Šarlija a Harc (2012) se domnívají, že likvidita je rysem majetku společnosti, který může být rychle přeměněn na hotovost. Firmy při svých činnostech drží určité množství likvidity, aby byly schopny včas plnit své závazky. Z tohoto důvodu Saleem a Rehman (2011) také zastávají názor, že řízení likvidity je velmi důležitým prvkem pro každou společnost $\mathrm{z}$ důvodu zachování schopnosti platit své závazky řádně a včas. 
Cílem článku je tedy zjistit vliv jednotlivých vybraných finančních ukazatelů na likviditu podniků ve vybraných odvětvích v České republice za období let 2000 až 2015. Za účelem dosažení a splnění stanoveného cíle bude zkoumána existence a charakter vztahu mezi vybranými finančními ukazateli (ukazatel debt equity ratio, rentabilita vlastního kapitálu, podíl fixních aktiv na celkových aktivech a podíl zisku před zdaněním a úrokovými náklady na celkových aktivech) a likviditou podniků vodvětvích jako je těžba a dobývání, zpracovatelský průmysl, stavebnictví, odvětví služeb a odvětví energetiky.

První kapitola tohoto článku bude zahrnovat přehled relevantní literatury. Druhá část práce bude zaměřena na použitou metodologii a data, kde budou popsány jednotlivé metody, jež budou potřebné pro naplnění stanoveného cíle. Následující část článku bude obsahovat výsledky a diskusi nad dosaženými výsledky. Poslední část bude věnována závěru, kde budou shrnuty veškeré zjištěné výsledky.

\section{Přehled relevantní literatury}

Williamson (1988), Schleifer a Vishny (1992) a Anderson (2002) se domnívají, že více likvidní společnosti v sobě zahrnují menší monitorovací náklady a náklady na likvidaci. Z tohoto důvodu vyšší likvidita zvyšuje pákový efekt neboli leverage. Na druhé straně, De Jong et al. (2008), Lipson a Mortal (2009), Šarlija a Harc (2012) tvrdí, že více likvidní společnosti bývají méně zadlužené, protože využívají dostatečnou firemní likviditu k vnitřnímu financování jednotlivých aktivit dané společnosti.

Cílem článku je tedy zjistit vliv jednotlivých finančních ukazatelů na likviditu podniků ve vybraných odvětvích v České republice. $Z$ tohoto důvodu by bylo vhodné zmínit studie, jež se likviditou podniků v České republice zabývaly. Bohužel existuje pouze několik málo studií zaměřených na likviditu podniků $\mathrm{v}$ České republice $\mathrm{z}$ pohledu, který je $\mathrm{v}$ tomto článku zkoumán. $Z$ tohoto důvodu bude přehled relevantní literatury doplněn o další studie, jež zkoumají likviditu podniků také v jiných zemích.

Anderson (2002) zkoumal vztah mezi firemní finanční strukturou, držbou likvidních aktiv a růstem společností působících v zemích jako je Belgie a Velká Británie. Pomocí regresní analýzy zkoumal faktory ovlivňující držbu likvidních aktiv a zjištoval vztah mezi podnikovou likviditou a kapitálovou strukturou pomocí následujících proměnných: likvidita (závislá proměnná, podíl součtu hotovosti, zůstatků na bankovních účtech a investic do oběžných aktiv na celkových aktivech) a nezávisle proměnné jako je podíl zisku před zdaněním a úroky na celková aktiva, dlouhodobý dluh, střednědobý dluh, krátkodobý dluh, výdaje na vědu a výzkum. Výsledky prokázaly pozitivní vztah mezi pákovým efektem a likviditou společnosti.

Jedním ze zdrojů financování mohou být odpisy, jež jsou spojovány s fixními aktivy. Z tohoto důvodu je vhodné prozkoumat vztah mezi likviditou podniků a odpisy prostřednictvím dlouhodobého majetku. Existuje však minimální počet studií, jež se zaměřují na tento vztah. Z tohoto důvodu byla do přehledu relevantní literatury zařazena studie, ve které se Mehar (2005) pokusil zjistit, zda hraje financování vlastním kapitálem ústřední roli při určování likvidní pozice společností v Pákistánu. Mehar (2005) se ve své studii zabýval vztahem mezi likviditou společností (závislá proměnná) a nezávislými proměnnými jako jsou fixní aktiva, čistý zisk po zdanění či nerozdělený zisk. Pomocí korelační analýzy zjistil, že likvidita společností pozitivně koreluje s fixními aktivy. Dle jeho názoru růst fixních aktiv povede $\mathrm{k}$ nárůstu odpisů, čímž se zvýší dostupnost finančních zdrojů bez poklesu peněžních prostředků. Zjistil také, že odpisy a jejich př́padný odpisový fond lze klasifikovat jako zdroj likvidity. Domníval se, že dlouhodobé zadlužení může zhoršit likvidní pozici dané společnosti. 
Výsledky studie také prokázaly pozitivní vztah mezi ziskem a likviditou společností, zatímco vztah mezi likviditou a nerozděleným ziskem byl vyhodnocen jako negativní.

Shah (2012) zkoumal vztah mezi rentabilitou a likviditou společností skrze analýzu pracovního kapitálu $\mathrm{v}$ Indii. Tato studie vyhodnocuje proměnné, jež mají vliv na ř́zení pracovního kapitálu, ziskovost a likviditu společností. Zkoumal vztah mezi likviditou podniků (závisle proměnná zahrnující běžnou likviditu) a rentabilitou (podíl zisku před zdaněním a úrokovými náklady na celkových aktivech). Autor studie dospěl k závěru, že existuje negativní vztah mezi likviditou podniků a rentabilitou.

Šarlija a Harc (2012) zkoumali vliv likvidity na kapitálovou strukturu chorvatských firem. Pomocí Pearsonova korelačního koeficientu zjištovali vztah mezi likviditou podniků a proměnnými jako je zadluženost, podíl nerozděleného zisku na kapitál. Zjišt'ovali také vztah mezi strukturou oběžných aktiv a pákovým efektem. Výsledky prokázaly, že existuje negativní vztah či korelace mezi likviditou podniků a pákovým efektem. Výsledky také prokázaly, že existuje statisticky významná korelace mezi pákovým efektem a oběžnými aktivy. Autoři studie také dospěli k závěru, že negativní vztah mezi likviditou podniků a krátkodobým pákovým efektem je významnější než pozitivní vztah mezi likviditou podniků a dlouhodobým pákovým efektem. Domnívali se, že čím více je společnost likvidní, tím méně je zadlužena. Autoři se také domnívají, že dlouhodobě zadlužené společností disponují větším objemem likvidních aktiv a lze je považovat za více likvidní. Zvýšená úroveň zásob bude mít za následek zvýšení pákového efektu. Výsledky studie také prokázaly, že růst hotovosti vede ke snížení krátkodobého a dlouhodobého pákového efektu.

Trippner (2013) analyzoval vztah mezi likviditou (okamžitá, pohotová a běžná) a ziskovostí (rentability aktiv - ROA, rentabilita vlastního kapitálu - ROE) v Polsku za období let 2002 až 2012. Pomocí korelační analýzy bylo zjištěno, že existuje pozitivní i negativní vztah mezi likviditou a rentabilitou aktiv a rentabilitou vlastního kapitálu.

Miloş (2015) zkoumal determinanty kapitálové struktury rumunských společností pomocí panelových dat. Do své studie použil proměnné zahrnující podíl celkových dluhů na celkových závazcích, rentabilitu aktiv, likviditu (poměr mezi oběžnými aktivy a krátkodobými závazky), fixní aktiva (podíl fixních aktiv na celkových aktivech) a velikost firmy (logaritmus celkových tržeb). Výsledky prokázaly, že existuje negativní vztah mezi likviditou podniků a pákovým efektem. Méně likvidní společnosti získávají potřebný kapitál prostřednictvím půjček. Firmy tak často preferují a využívají krátkodobé úvěry pro financování svých aktivit v době, kdy nedisponují dostatečným objemem likvidity.

Růčková (2015) analyzovala vliv likvidity a rentability na využívání cizích zdrojů financování v rámci podniků působících ve zpracovatelském průmyslu v zemích V4. Zkoumala vztah mezi využitím cizích zdrojů (debt equity ratio) a likviditou a rentabilitou vlastního kapitálu. Výsledky prokázaly pozitivní vztah mezi likviditou podniků a využitím cizích zdrojů financování v České republice. V souladu se závěry studie lze konstatovat, že růst likvidity je doprovázen nárůstem cizích zdrojů financování.

\section{Metodologie a data}

Vzhledem k tomu, že je tento článek zaměřen na likviditu podniků působících v České republice, je vhodné zmínit, že jednotlivá odvětví ekonomiky se zapojují v různé míře do spotřeby a výroby národního hospodářství. Dle Českého statistického úřadu mají odvětví jako je těžba a dobývání, zpracovatelský průmysl, stavebnictví, odvětví služeb a energetiky 
největší podíl na výkonu ekonomiky. Z tohoto důvodu je tento článek zaměřen na zjištění vztahu mezi likviditou podniků a vybranými finančními ukazateli v odvětvích jako je těžba a dobývání, zpracovatelský průmysl, stavebnictví, odvětví služeb a odvětví energetiky.

Veškeré finanční údaje byly čerpány z Ministerstva průmyslu a obchodu v České republice. Soubor dat zahrnuje časovou řadu za období let 2000 až 2015, kdy jsou veškerá data na roční bázi. Data jsou základem pro použití korelační a regresní analýzy. Zkoumaný vzorek zahrnuje 27 podniků z odvětví těžby a dobývání, 1265 podniků ze zpracovatelského průmyslu, 166 podniků ze stavebnictví, 646 podniků ze sektoru služeb a 80 podniků z oblasti energetiky. Cílem článku je tedy zjistit vliv vybraných finančních ukazatelů na likviditu podniků ve vybraných odvětvích v České republice za období let 2000 až 2015. Za účelem dosažení a splnění stanoveného cíle bude zkoumána existence a charakter vztahu mezi vybranými finančními faktory (ukazatel debt equity ratio, rentabilita vlastního kapitálu, podíl fixních aktiv na celkových aktivech a podíl zisku před zdaněním a úrokovými náklady na celkových aktivech) a likviditou společností v odvětvích jako je těžba a dobývání, zpracovatelský průmysl, stavebnictví, odvětví služeb a odvětví energetiky.

Na základě uvedených studií a formulovaných cílů lze definovat vztah mezi likviditou podniků a vybranými finančními ukazateli, kdy tento vztah bude zjišt'ován pro jednotlivá námi vybraná odvětví (těžba a dobývání, zpracovatelský průmysl, stavebnictví, odvětví služeb a odvětví energetiky). Empirická část bude poté zaměřena na vliv jednotlivých finančních ukazatelů na likviditu podniků neboli, jak vybrané finanční ukazatele ovlivňují likviditu podniků v České republice.

Pro zjištění vztahu mezi likviditou podniků a vybranými finančními ukazateli bude použita korelační analýza, regresní analýza a OLS metoda, tedy metoda nejmenších čtverců. Jako první lze odhadnout vztah mezi likviditou podniků a jednotlivými finančními ukazateli pomocí korelační analýzy. Tento vztah může být vyjádřen prostřednictvím následující rovnice (1):

$$
K_{X Y}=\frac{\operatorname{cov}(X, Y)}{\sigma_{X} \sigma_{Y}}
$$

Kde $\mathrm{X}$ je střední hodnota matice hodnot likvidity podniků a $\mathrm{Y}$ je střední hodnota matice hodnot debt equity ratio, rentability vlastního kapitálu, podílu fixních aktiv na celkových aktivech a podílu zisku před zdaněním a úrokovými náklady na celkových aktivech ve vybraných odvětvích České republiky. Výsledné hodnoty korelační analýzy by se měly pohybovat $\mathrm{v}$ intervalu od -1 do 1 , kdy hodnoty blížící se $\mathrm{k} 1$ signalizují pozitivní závislost mezi závisle proměnnou a nezávisle proměnnou, což lze interpretovat způsobem, kdy $\mathrm{s}$ růstem vybraných finančních ukazatelů představovaných pomocí ukazatele debt equity ratio, rentability vlastního kapitálu, podílu fixních aktiv na celkových aktivech a podílu zisku před zdaněním a úrokovými náklady na celkových aktivech, roste také likvidita podniků. Hodnoty blížící se -1 mají zcela opačný negativní vztah. Hodnoty blížící se 0 vypovídají o vzájemné nezávislosti proměnných, kdy skutečnosti, že mezi analyzovanými proměnnými nelze jednoznačné určit závislost.

Při sestavování regresního modlu lze vycházet ze studie Anderson (2002), kdy vztah mezi likviditou podniků a vybranými finančními ukazateli lze odhadnout pomocí následující rovnice v obecném tvaru (2): 


$$
L_{t}=\beta_{0}+\beta_{1} X_{1 t}+\beta_{2} X_{2 t} \ldots \ldots \ldots \ldots+\beta_{n} X_{n t}+\varepsilon_{t}
$$

V souladu se studiemi Anderson (2002), Mehar (2005), Trippner (2013) a Růčková (2015), byly stanoveny následující proměnné: ukazatel debt equity ratio (DER), rentabilita vlastního kapitálu (ROE), podíl fixních aktiv na celkových aktivech (FATTA) a podíl zisku před zdaněním a úrokovými náklady na celkových aktivech (EBIT). Závisle proměnná $L_{t}$ představuje ukazatel bě̌né likvidity (L3) podniků v České republice v čase $t, X_{n t}$ představují námi vybrané finanční ukazatele, jež mohou mít vliv na vývoj likvidity podniků v České republice. Tyto faktory zahrnují ukazatel debt equity ratio (DER), rentabilita vlastního kapitálu (ROE), podíl fixních aktiv na celkových aktivech (FATTA) a podíl zisku před zdaněním a úrokovými náklady na celkových aktivech (EBIT). Symboly jako $\beta_{0}$ a $\varepsilon_{t}$ představují konstantu modelu a reziduální složku modelu.

Tabulka 1: Popis použitých proměnných

\begin{tabular}{|l|l|l|}
\hline Proměnné & Výpočet & Očekávaný vztah \\
\hline Ukazatel běžné likvidity (L3) & Oběžná aktiva / krátkodobé závazky & Závisle proměnná \\
\hline Ukazatel debt equity ratio (DER) & Cizí zdroje / vlastní zdroje & - \\
\hline Rentabilita vlastního kapitálu (ROE) & Čistý zisk / vlastní kapitál & + \\
\hline Fixní aktiva (FATTA) & Fixní aktiva / celková aktiva & + \\
\hline $\begin{array}{l}\text { Zisk před zdaněním a úrokovými } \\
\text { náklady (EBIT) }\end{array}$ & $\begin{array}{l}\text { Zisk před zdaněním a úrokovými } \\
\text { náklady / celková aktiva }\end{array}$ & $+/-$ \\
\hline
\end{tabular}

Zdroj: Vlastní zpracování

Tabulka 1 představuje popis použitých proměnných, jež jsou zastoupeny skrze následující proměnné: ukazatel debt equity ratio, rentabilita vlastního kapitálu, podíl fixních aktiv na celkových aktivech a podíl zisku před zdaněním a úrokovými náklady na celkových aktivech. Výběr proměnných je založen na výše uvedených studiích.

Ukazatel běžné likvidity je velmi důležitým ukazatelem, nebot' pouze likvidní podnik je schopen uhradit své splatné závazky včas a ve stanovené výši. Společnost je likvidní pouze v době, kdy disponuje dostatečným množstvím peněžních prostředků na včasnou úhradu svých krátkodobých závazků. Příliš vysoká hodnota likvidity bývá zpravidla doprovázená nižšími hodnotami vlastního kapitálu (rentability vlastního kapitálu), jež je spojováno $\mathrm{s}$ konzervativním př́stupem. Na druhou stranu, firmy, jež disponují př́íliš nízkými hodnotami likvidity, zpravidla využívají k financování svých aktivit cizí zdroje.

Ukazatel debt equity ratio, tzv. leverage poměřuje cizí zdroje k vlastnímu kapitálu. Vyjadřuje tedy poměr cizích zdrojů vůči vlastním zdrojům při financování podniku. Čím vyšší je hodnota ukazatele, tím vyšší je poměr cizích zdrojů ke zdrojům vlastním tedy k vlastnímu kapitálu, což může signalizovat také vyšší riziko pro věřitele. Jestliže je hodnota tohoto ukazatele 1, vlastní kapitál a cizí zdroje se podílejí na financování firmy ve stejné výši. Vyšší zadluženost kromě vyšší úrovně rizikovosti firmy na jedné straně, může také znamenat větší objem levnějších zdrojů financování, kdy náklady na cizí zdroje financování bývají zpravidla levnější než náklady na vlastní kapitál. Společnosti, jež disponují příliš nízkou úrovní likvidity, obvykle využívají cizí zdroje k financování jejich aktivit. Z tohoto důvodu lze očekávat negativní vztah mezi likviditou společností a ukazatelem debt equity ratio. Tento očekávaný vztah je v souladu se studií Miloş (2015), jež ve své studii potvrdil negativní vztah mezi likviditou podniků a ukazatelem debt equity ratio.

Ukazatel rentability vlastního kapitálu, tzv. ROE je důležitým ukazatelem zejména pro majitele firmy či její konkurenci. Vyjadřuje, jak efektivně společnost využívá své vlastní 
prostředky, tedy prostředky vlastníků firmy. Rentabilita vlastního kapitálu může ovlivnit také náklady na externí financování (cizí zdroje). Je tedy očekáván pozitivní vztah mezi likviditou podniků a rentabilitou vlastního kapitálu, což je v souladu se studií Trippner (2013). Více ziskové společnosti mohou použitý nerozdělený zisk $\mathrm{k}$ financování jejich investičních projektů.

Další nezávisle proměnnou je podíl fixních aktiv na celkových aktivech. Vyšší hodnota fixního majetku v sobě zahrnuje také vyšší hodnotu likvidních aktiv. Růst fixních aktiv může vést $\mathrm{k}$ nárůstu odpisů, čímž se zvýší dostupnost finančních zdrojů bez poklesu peněžních prostředků. Dlouhodobý majetek tedy hraje kličcovou roli v př́padě zajištění potřebných bankovních úvěrů a půjček. Nízká úroveň dlouhodobého majetku by mohla snížit celkový objem dostupných peněžních prostředků, kterých by mohla daná společnost dosáhnout. Naopak vyšší úroveň dlouhodobého majetku by mohla zajistit levnější cizí zdroje a snížit tak věřitelské riziko. Na druhou stranu, společnosti dávají přednost krátkodobému zadlužování před zadlužením dlouhodobým, kdy $\mathrm{v}$ takovém to př́padě není zajištění dlouhodobým majetkem př́liš důležité. Společnosti $s$ vyšší hodnotou fixních aktiv dávají přednost při financování svých aktivit nerozdělenému zisku či vlastnímu kapitálu před zvýšením zadluženosti. Na základě výše uvedených skutečností se očekává pozitivní vztah mezi likviditou společností a podílem fixních aktiv na celkových aktivech.

Společnosti $\mathrm{s}$ vyšší úrovní zisku bývají zpravidla více zadlužené vzhledem $\mathrm{k}$ vyšší důvěryhodnosti $\mathrm{v}$ očích potencionálních věřitelů. $\mathrm{Na}$ druhou stranu více ziskové podniky mohou použít nerozdělený zisk za účelem financování svých aktivit či investičních projektů. Příliš vysoká hodnota likvidity je obvykle doprovázená nižšími hodnotami zisku a následně ziskovosti, jež je spojována s konzervativnějším prístupem. Nicméně Trippner (2013) potvrdil jak negativní, tak také pozitivní vztah mezi likviditou podniků a podílem zisku před zdaněním a úrokovými náklady na celkových aktivech. V souladu s těmito skutečnostmi není zcela jasné, jaký vztah mezi likviditou a tímto ukazatelem očekávat. $Z$ tohoto důvodu bude tento výsledný vztah stanoven či určen pomocí regresní analýzy.

\section{Výsledky a diskuse}

Tato část článku je zaměřena na výsledky korelační a regresní analýzy včetně jejich následných komentářů. Jako první lze odhadnout či určit vztah mezi likviditou podniků a vybranými finančními ukazateli pomocí korelační analýzy. Následující tabulka (2) znázorňuje vzájemnou závislost sledovaných proměnných ve vybraných odvětvích v České republice.

Tabulka 2: Korelační vztah mezi likviditou podniků a vybranými finančními ukazateli ve vybraných odvětvích České republiky

\begin{tabular}{|l|l|l|l|l|l|}
\hline & & DER & ROE & FATTA & EBIT \\
\hline Těžba a dobývání & likvidita (L3) & 0.327676 & -0.213947 & -0.727376 & -0.309519 \\
\hline Zpracovatelský & likvidita (L3) & 0.141195 & 0.271813 & -0.423893 & 0.216988 \\
\hline Stavebnictví & likvidita (L3) & -0.391987 & 0.206347 & -0.100032 & 0.160306 \\
\hline Služby & likvidita (L3) & -0.133967 & -0.196059 & -0.304793 & -0.296926 \\
\hline Energetika & likvidita (L3) & -0.473280 & 0.388364 & 0.254006 & 0.320249 \\
\hline
\end{tabular}

Zdroj: Vlastní zpracování

Tabulka 2 znázorňuje korelační vztah mezi likviditou podniků (závisle proměnná) a nezávisle proměnnými jako je ukazatel debt equity ratio, rentabilita vlastního kapitálu, podíl fixních aktiv na celkových aktivech a podíl zisku před zdaněním a úrokovými náklady na celkových aktivech. $Z$ tabulky (2) je zřejmé, že korelační vazba mezi proměnnými je ve všech vybraných odvětvích zcela odlišná. 
Vztah mezi likviditou podniků a ukazatelem debt equity ratio (DER), rentabilitou vlastního kapitálu (ROE) a podílem zisku před zdaněním a úrokovými náklady na celkových aktivech se jeví jako nekorelovaný ve všech námi analyzovaných odvětvích. Výsledné hodnoty korelace se blíží nule, z čeho lze usuzovat, že mezi proměnnými existuje téměř minimální závislost. Naopak největší korelace byla zaznamenána v energetickém odvětví. Hodnota korelačního koeficientu $\mathrm{v}$ rámci vztahu mezi likviditou podniků a ukazatelem debt equity ratio činila - 0,473280, což potvrzuje existenci negativní závislosti mezi těmito dvěma proměnnými. Lze tedy konstatovat, že pokles ukazatele debt equity ratio by měl vést $\mathrm{k}$ růstu likvidity podniků působících ve vybraných odvětvích v České republice. Byla také zjištěna pozitivní korelace mezi likviditou podniků a rentabilitou vlastního kapitálu (ROE), kdy korelační koeficient dosahoval hodnoty 0,388364. Korelační koeficient pro vztah mezi likviditou a podílem zisku před zdaněním a úrokovými náklady na celkových aktivech (EBIT) činil 0,320249. Oba výsledné korelační koeficienty signalizují pozitivní závislost výše zmíněných proměnných na likviditu podniků. Jinými slovy řečeno, růst rentability vlastního kapitálu (ROE) a podílu zisku před zdaněním a úrokovými náklady na celkových aktivech (EBIT) vyvolá růst likvidity podniků působících v odvětví energetiky v České republice.

Výsledné hodnoty také naznačují, že vztah mezi likviditou podniků a podílem fixních aktiv na celkových aktivech (FATTA) se jeví jako nekorelovaný ve zpracovatelském průmyslu, stavebnictví, odvětví služeb a energetiky. V rámci těžby a dobývání byla zaznamenána silnější negativní korelace mezi likviditou podniků a výše zmíněným ukazatelem. Korelační koeficient $-0,727376$ se blížil hodnotě -1 , z čehož lze usuzovat, že s poklesem podílu fixních aktiv na celkových aktivech (FATTA) dojde $\mathrm{k}$ růstu firemní likvidity $\mathrm{v}$ odvětví těžby a dobývání v rámci České republiky.

Pomocí korelační analýzy jsme pouze zjistili, zda existuje pozitivní vztah, negativní vztah či žádný vztah mezi likviditou podniků působících $\mathrm{v}$ námi vybraných odvětvích v České republice a nezávisle proměnnými (vybrané finanční ukazatele). Pomocí regresní analýzy a metody nejmenších čtverců se pokusíme určit a potvrdit nejen směr závislosti mezi proměnnými, ale také, jak významný bude tento výsledný vztah mezi likviditou podniků a vybranými finančními ukazateli. Tento vztah lze vyjádřit pomocí následující rovnice (3):

$$
L_{t}=\beta_{0}+\beta_{1} * D E R_{1 t}+\beta_{2} * R O E_{2 t}+\beta_{3} * F A T T A_{3 t}+\beta_{4} * E B I T_{4 t}+\varepsilon_{t}
$$

Pro zpracování regresní analýzy byl použit ekonometrický software Eviews 9. Před odhadováním modelu bylo nejprve potřeba otestovat, zda jsou časové řady stacionární či nikoli. Pro tento účel byl použit Levin, Lin a Chu test pro zjištění existence jednotkových kořenů u jednotlivých proměnných. Výsledky prokázaly, že časové řady jednotlivých proměnných nejsou stacionární. Z tohoto důvodu byla přijata nulová hypotéza jednotkového kořene. Na základě tohoto výsledku bylo nutno použít první diferenci, na jejímž základě vyšly časové řady jako stacionární a mohly tak být použity v regresní analýze. Metoda nejmenších čtverců má několik předpokladů. Nejprve, pro ověření heteroskedasticity byl použit Whitův test, na jejímž základě byla potvrzena homoskedasticita. Pro ověření multikolinearity jsme použili korelační koeficient $\mathrm{v}$ rámci korelační matice. Ta prokázala, že neexistuje silná korelační vazba mezi proměnnými. Také bylo potvrzeno normální rozdělení pravděpodobnosti. Pomocí testu Durbin-Watson jsme prokázali nepř́ítomnost autokorelace.

Tabulka 3 znázorňuje výsledný vztah mezi likviditou podniků (závisle proměnná) a vybranými finančními ukazateli (nezávisle proměnné). Statisticky významný vliv vybraných finančních ukazatelů na likviditu podniků byl prokázán pouze ve dvou odvětvích, konkrétně v 
odvětví služeb a energetiky. Z tohoto důvodu tabulka 3 znázorňuje pouze výsledky v rámci těchto dvou odvětví, kdy jsme odhadovali vztah mezi likviditou podniků a vybranými finančními ukazateli jako je ukazatel debt equity ratio, rentabilita vlastního kapitálu, podíl fixních aktiv na celkových aktivech a podíl zisku před zdaněním a úrokovými náklady na celkových aktivech. Statisticky nevýznamné vztahy v ostatních odvětvích nebyly do výsledné tabulky zahrnuty. Bylo zjištěno, že některé vybrané finanční ukazatele nebyly statisticky významné, z čehož nejsme schopni potvrdit vliv těchto proměnných na likviditu podniků v České republice. $Z$ tohoto důvodu jsou v tabulce 3 prezentovány pouze statisticky významné proměnné, jež měly dopad na likviditu podniků v České republice.

Tabulka 3: Odhadovaný vztah mezi likviditou podniků a vybranými finančními ukazateli ve vybraných sektorech České republiky

\begin{tabular}{|l|l|l|l|l|}
\hline & \multicolumn{2}{|c|}{ Odvětví energetiky } & \multicolumn{2}{c|}{ Odvětví služeb } \\
\hline & Koeficient & t-statistics & Koeficient & t-statistics \\
\hline Konstanta & 0.004798 & 0.104066 & -0.019634 & -0.425631 \\
\hline DER & $-0.624761 * *$ & -2.516879 & & \\
\hline FATTA & & & $-2.612102 * *$ & -2.138445 \\
\hline ROE & $3.869004 * *$ & 2.758368 & & 0.397842 \\
\hline R-squared & \multicolumn{2}{|c|}{0.634676} & & 0.156979 \\
\hline Adjusted R-squared & \multicolumn{3}{|c|}{0.472310} & 1.651734 \\
\hline F-statistic & \multicolumn{3}{|c|}{3.908916} & 0 \\
\hline Prob(F-statistic) & \multicolumn{2}{|c|}{0} & \multicolumn{2}{c|}{1.821626} \\
\hline Durbin-Watson stat & \multicolumn{2}{|c|}{1.893395} & \\
\hline
\end{tabular}

Zdroj: Vlastní zpracování

Poznámka: * představuje $1 \%$ hladinu významnosti, ** představuje $5 \%$ hladinu významnosti, $* * *$ představuje $10 \%$ hladinu významnosti

Z tabulky 3 vyplývá, že různé námi zkoumané proměnné měly vliv na likviditu podniků ve vybraných odvětvích v České republice za období let 2000 až 2015. Byl zkoumán vztah mezi likviditou podniků v České republice a vybranými finančními ukazateli v odvětvích jako je těžba a dobývání, zpracovatelský průmysl, stavebnictví, odvětví služeb a energetiky. Statisticky významné proměnné byly zjištěny pouze ve dvou odvětvích, konkrétně v odvětví služeb a energetiky. $Z$ tohoto důvodu tabulka 3 znázorňuje pouze výsledky v rámci těchto dvou odvětví, kdy jsme odhadovali vliv nezávisle proměnných jako je ukazatel debt equity ratio, rentabilita vlastního kapitálu, podíl fixních aktiv na celkových aktivech a podíl zisku před zdaněním a úrokovými náklady na celkových aktivech na likviditu podniků.

Některé z těchto proměnných nebyly statisticky významné, z čehož nejsme schopni potvrdit či prokázat vliv těchto proměnných na likviditu podniků v České republice. $Z$ tohoto důvodu jsou $\mathrm{v}$ tabulce 3 prezentovány pouze statisticky významné proměnné, jež měly dopad na likviditu podniků v České republice.

Co se týče odvětví energetiky, byl prokázán negativní vliv ukazatele debt equity ratio (DER) na likviditu podniků v České republice. Z výsledků vyplývá, že růst ukazatele debt equity ratio o jednotku vyvolá pokles likvidity podniků o 0,624761 jednotek. Tento vztah je potvrzen ve studii Miloş (2015), kde byl zjištěn negativní vztah mezi likviditou společností a ukazatelem debt equity ratio. Méně likvidní společnosti získávají potřebný kapitál prostřednictvím půjček, kdy firmy často preferují krátkodobé zadlužení $\mathrm{v}$ př́padě nedostatečného objemu likvidity. 
Výsledky také prokázaly pozitivní vliv rentability vlastního kapitálu (ROE) na likviditu podniků v energetickém odvětví. Výsledky naznačují, že zvýšení rentability vlastního kapitálu o jednotku vyvolá růst likvidity společností o 3,869004 jednotek. Tento výsledný vztah je v souladu se závěry studie Trippner (2013), který potvrdil existenci pozitivního vztahu mezi likviditou společností a rentabilitou vlastního kapitálu (ROE). Více ziskové společnosti mohou použít nerozdělený zisk k financování jejich investičních aktivit. Lze tedy očekávat, že čím více je podnik likvidní, tím méně se stává zadluženým.

Co se týče odvětví služeb, byl prokázán negativní vliv podílu fixních aktiv na celkových aktivech (FATTA) na likviditu podniků. Růst tohoto ukazatele o jednotku bude mít za následek pokles firemní likvidity o 2,612102 jednotek. Tento výsledný vztah není v souladu s žádnou výše uvedenou studií. Výsledný vztah může být vysvětlován na základě tvrzení, kdy aktiva dané společnosti lze rozdělit na dlouhodobá aktiva a oběžná aktiva. Ukazatel likvidity v sobě zahrnuje oběžná aktiva. Růst likvidity by měl být proto doprovázen také růstem oběžných aktiv za poklesu fixních aktiv. Na základě této skutečnosti lze tedy vyvodit negativní vztah mezi likviditou a ukazatel podílu fixních aktiv na celkových aktivech. Vliv ostatních vybraných finančních ukazatelů na likviditu podniků působících v jiných námi zvolených odvětvích nebyl prokázán.

Veškeré dosažené výsledné vztahy korespondují se závěry korelační analýzy, pomocí níž bylo zjištěno, zda existuje pozitivní, negativní či žádný vztah mezi likviditou podniků a nezávislými proměnnými. Na kvalitu modelu upozorňuje také Durbin-Watson test, jež svými výslednými hodnotami potvrzuje, že daná rezidua nejsou autokorelované a nejsou zatížená autokorelací. $\mathrm{V}$ opačném př́ípadě by mohlo dojít $\mathrm{k}$ nadhodnocení vypovídací schopnosti modelu či podhodnocení reziduí. Optimální či přijatelné hodnoty Durbin-Watson testu se pohybují v rozmezí 1,8 až 2,2. Na druhou strany je nutno vzít v úvahu vypovídací schopnost modelu, jež lze charakterizovat či odhadovat pomocí hodnot R- squared a Adjusted Rsquared. Z výsledků lze usuzovat, že vypovídací schopnost modelu představovaná pomocí hodnot R-squared a Adjusted R- squared je poměrně nízká v rámci odvětví služeb. Hodnota R-squared činila přibližně $40 \%$ a hodnota Adjusted R-squared přibližně $15 \%$. V rámci energetického odvětví, hodnota R-squared představovala přibližně $63 \%$ a hodnota Adjusted R-squared činila 47\%. Na základě těchto výsledků je zřejmé, že likvidita společností je také ovlivněna dalšími faktory (proměnnými), jež dosud nebyly testovány. Na základě této skutečnosti lze tedy vymezit další prostor pro další výzkum v budoucnu.

\section{Závěr}

Cílem článku bylo zjistit vliv vybraných finančních ukazatelů na likviditu podniků ve vybraných odvětvích v České republice za období let 2000 až 2015. Za účelem dosažení a splnění stanoveného cíle byla zkoumána existence a charakter vztahu mezi vybranými finančními faktory (ukazatel debt equity ratio, rentabilita vlastního kapitálu, podíl fixních aktiv na celkových aktivech a podíl zisku před zdaněním a úrokovými náklady na celkových aktivech) a likviditou společností v odvětvích jako je těžba a dobývání, zpracovatelský průmysl, stavebnictví, odvětví služeb a odvětví energetiky.

V empirické části byl zjišt'ován vliv jednotlivých vybraných finančních ukazatelů (ukazatel debt equity ratio, rentabilita vlastního kapitálu, podíl fixních aktiv na celkových aktivech a podíl zisku před zdaněním a úrokovými náklady na celkových aktivech) na likviditu podniků působících v České republice v rámci odvětví těžby a dobývání, stavebnictví, zpracovatelského průmyslu, odvětví služeb a energetiky. 
Veškeré zjištěné výsledky korespondovaly se závěry korelační analýzy, pomocí níž byl zjištěn vztah mezi likviditou podniků a nezávisle proměnnými. Byl prokázán pozitivní vliv rentability vlastního kapitálu (ROE) na likviditu společností v rámci energetického odvětví v České republice. Lze tedy očekávat, že s růstem rentability vlastního kapitálu dojde ke zvýšení likvidity podniků. Na druhou stranu, byl prokázán negativní vliv ukazatele debt equity ratio na vývoj podnikové likvidity v energetickém odvětví. Výsledný vztah lze interpretovat tvrzením, že pokles ukazatele debt equity ratio bude mít za následek růst firemní likvidity. Zcela odlišná situace byla zaznamenána $\mathrm{v}$ rámci odvětví služeb, kdy byl prokázán statisticky významný vliv ukazatele fixních aktiv na celkových aktivech na likviditu společností. Výsledky prokázaly negativní vliv tohoto ukazatele na likviditu společností. Lze tedy očekávat, že s poklesem ukazatele podílu fixních aktiv na celkových aktivech vzroste likvidita společností. Vliv ostatních vybraných finančních ukazatelů na likviditu podniků působících v jiných námi zvolených odvětvích nebyl prokázán.

Vztah či vliv ostatních zmíněných proměnných na likviditu podniků $\mathrm{v}$ ostatních analyzovaných odvětvích byl prokázán jako statisticky nevýznamný, z čehož nejsme jednoznačně schopni určit vliv či dopad těchto proměnných na likviditu podniků u ostatních zmíněných odvětví v České republice jako je odvětví těžby a dobývání, zpracovatelský průmysl a stavebnictví.

Na základě nízké vypovídací schopnosti modelu je zřejmé, že likvidita podniků v České republice může být také ovlivněna dalšími námi netestovanými proměnnými, čímž se otevírá prostor pro další výzkum v budoucnu.

\section{Poděkování}

„Tento článek vznikl za podpory Ministerstva školství, mládeže a tělovýchovy ČR v rámci Institucionální podpory na dlouhodobý koncepční rozvoj výzkumné organizace v roce 2017““

\section{Literatura}

[1] ANDERSON, R. W., 2002. Capital structure, firm liquidity and growth. Working papersresearch series. National Bank of Belgium. [online] [vid. 1. února 2017]. Dostupné z:: www.nbb.be/doc/ts/publications/wp/WP27en.pdf.

[2] DE JONG, A., R. KABIR and T. T. NGUYEN, 2008. Capital structure around the world: the roles of firm and country-specific determinants. Journal of banking and finance, 32, 1954-1969.

[3] LIPSON, M. L. and S. MORTAL, 2009. Liquidity and capital structure. Journal of Financial Markets. 12(4), 611-644. ISSN 1386-4181.

[4] MEHAR, A., 2005. Impacts of equity financing on liquidity position of a firm. Applied Financial Economics, Vol. 15, 425-438. ISSN 1466-4305.

[5] MILOŞ, M. C., 2015. Capital Structure Determinants. Evidence from the Romanian Listed Companies. Analele Universitatii 'Eftimie Murgu' Resita. Fascicola II. Studii Economice, 129-134. ISSN 2344-6315.

[6] MYERS, S. C., 2001. Capital structure. The journal of economic perspectives, 15(2),81102.

[7] RŮČKOVÁ, P., 2015. Impact of Liquidity and Profitability on Use of Debt Finance Sources of Companies in Manufacturing Industry in V4 Countries. Acta academica Karviniensia, 15(3), 69-79. ISSN 1212-415X. 
[8] SALEEM, Q. and U. R. REHMAN, 2011. Impacts of liquidity ratios on profitability. Interdisciplinary Journal of Research in Business, 1(7). 95-98. ISSN 2249-4588.

[9] SHAH, P., 2012. Evaluation of Profitability and Liquidity Relationship through Multivariate Working Capital Analysis. A Management Journal, 3(2),177. ISSN 23485302.

[10] SCHLEIFER, A. and R. W. VISHNY, 2001. Stock Market Driven Acquisitions. Journal of Financial Economics [online]. [vid. 1. února 2017]. Dostupné z: papers.ssrn.com/sol3/papers.cfm?abstract_id=278563.

[11] STULZ, R., 1990. Managerial discretion and optimal financing policies. Journal of financial Economics, 26(1), 3-27. ISSN 0304-405X

[12] ŠARLIJA, N. and M. HARC, 2012. The impact of liquidity on the capital structure: a case study of Croatian firms, Business Systems Research, 3(1), 30-36.

[13] TRIPPNER, P., 2013. Analysis of Financial Liquidity Management in the Enterprise and its Impact on the Profitability. $494-501$.

[14] WILLIAMSON, O. E., 1988. Corporate Finance and Corporate Governance. Journal of Finance, 43(3), 567-591. ISSN 1540-6261. 